\title{
Diversity, distribution and ecology of the genus Polyporus south of Western Siberia (north Asia)
}

\section{Vlasenko VA and Vlasenko AV}

Central Siberian Botanical Garden, Siberian Branch, Russian Academy of Sciences, Zolotodolinskaya 101, Novosibirsk, 630090, Russian federation.

Vlasenko VA, Vlasenko AV 2015 - Diversity, distribution and ecology of the genus Polyporus south of Western Siberia (north Asia). Current Research in Environmental \& Applied Mycology 5(2), 82-91, Doi 10.5943/cream/5/2/2

\begin{abstract}
Fourteen species of the genus Polyporus were identified based on the collection from lowland and mountain areas of south Western Siberia. The list of identified species are presented. Key to identification of fungi is given. Pictures of fruit bodies are given. The analysis of the substrate, habitat and zonal distribution was carried out. Substrate of fungi represented 13 species of angiosperms, 3 species of gymnosperms woody plants and steppe grasses. The largest number of species growing on willows, aspen and birch. Ten species were found in the plain area, 14 species were found in the mountain systems. Most diversity of species observed in the aspen-fir forests "Chernevaya taiga".
\end{abstract}

Key words - diversity - distribution - Polyporus - Siberia - north Asia - ecology

\section{Introduction}

Polyporus P. Micheli ex Adans. - is a type genus of the family Polyporaceae. The genus is quite old. Periodically it has been fragmented into smaller genera, but it is still considered as a "mega-genus".

The main features of the genus are fruiting bodies with a cap, often well-developed, seldom rudimentary, simple or branched stipe, dimitic hyphal system with arboriform skeleto-binding hyphae, cylindrical, smooth basidiospores, cystida in hymenium are absent, causes white rot of wood.

Some species of the genus Polyporus have medicinal properties, like other polyporoid fungi (Lindequist et al. 2005, Teplyakova et al. 2012). Information on their distribution is of great interest.

The classic monograph of Núñez \& Ryvarden (1995) describes 32 species of the genus. Considering resurrected species (14 species), as well as discovered and described recently as new for science (14 species), the genus can be increased up to 50 species. In this paper, we consider this genus in the broad sense (s.1.).

The genus Polyporus is poorly studied in Russia, especially substrate spectrum, habitat and zonal distribution. Their number makes 10 in the most well-studied regions, and the largest number of species is known in the Sverdlovsk region. Today 19 species of this genus have been identified in Russia, including P. admirabilis Peck, P. vassilievae Thorn, P. leprieurii Mont., P. mikawai Lloyd, P. mongolicus (Pilát) Y.C. Dai, discovered on the Russian Far East. 
Before we started our research in the south of Western Siberia the largest number of species were known for the Altai Republic. This information is based on published findings and samples of herbarium collections obtained from field collections of aphyllophoroid fungi in various taiga communities of the central districts of the Altai Republic, especially on Lake Teletskoe (Kovalenko 1992, Barsukova 1997, 1998, 1999, Mukhin et al. 2008). Are known collections of A. Zhukov and E. Zhukov from forest-steppe areas of south Western Siberia and Salair Ridge (Zhukov 1980, Zhukov 1995). The samples of fungi from the collections were studied in the herbarium of the Komarov Botanical Institute of the Russian Academy of Sciences (LE), they are presented by the collections of R. Zinger and M.A. Bondartseva.

For the first time for the Altai Krai we have indicated the following species $P$. alveolaris, $P$. arcularius, $P$. tuberaster, $P$. umbellatus, for the Altai Republic $-P$. choseniae, for the Novosibirsk Oblast - P. ciliatus, P. tubaeformis (Vlasenko 2010, 2011). The frequency of occurrence of species was identified, the distribution of species due to the substrates, types of plant communities, latitudinal zones and high-altitude zones was demonstrated.

\section{Materials \& Methods}

We used the traditional methods to collect the fruiting bodies in field expeditions (Gilbertson \& Ryvarden 1986, Ryvarden \& Melo, 2014). Collected fruiting bodies of fungi were dried. They were placed in the microwave for some time to get rid of the larvae of fungus beetles. Then they were placed in zip bags and paper bags for storage in the herbarium in cardboard boxes. Species of fungi were identified, morphological and anatomical characters were studied. Herbarium specimens are stored in CSBG SB RAS (NS), Novosibirsk.

Stereomicroscope Carl Zeiss Stemi DV4 and light microscope Carl Zeiss Axiolab RE were used to identify the fungi. Detailed study of the anatomical and morphological features was performed on a light microscope Carl Zeiss Axioskop-40 and stereo microscope Carl Zeiss Stereo Discovery V 12. For coloring preparations from dried herbarium material was used Melzer's reagent. For photographing fruiting bodies and habitats of fungi we used a Panasonic-Lumix DFCXZ7 camera.

Synopsis of species is based on herbarium specimens, 182 samples were collected and identified by the authors of this publication. We studies 66 samples in the herbarium NS collected mainly by N. Perova and A. Zhukov (principally from pine forests and taiga of Salair Ridge), 44 of which were determined by us. We also examined 10 samples from the herbarium LE. According to the literature data, we identified one location for $P$. alveolaris on Rhododendron from Lake Teletskoe (Barsukova, 1998) and one location for P. rhizophilus from South-Eastern Altai (Mukhin et al., 2008). Numbers of the herbarium specimens in the synopsis are listed only for the herbarium LE. Frequency of species according to Stephenson \& Laursen (1993). It is based on the proportion of species with respect to the total number of records ( 260 records in this study): rare ( $<0.5 \%$ of all records), occasional ( $>0.5-1.5 \%$ of all records), common $(>1.5-3 \%$ of all records), abundant (>3\% of all records).

List of abbreviations: AK - Altai Krai, AR - Altai Republic, KO - Kemerovo Oblast, NO Novosibirsk Oblast, d. - district, s. - settlement, v. - village, b.g. - botanical garden, hab. - habitats (in the type of plant community). loc. - localities.

\section{Studied localities and vegetation types}

The study area is located in the northern Asia, and corresponds to south of Western Siberia (see Fig. 1), including lowland areas of the West Siberian Plain and a part of the Altai-Sayan mountain area (Altai Mts., Salair Ridge, Gornaya Shoriya).

\section{Plain area \\ Steppe zone \\ Steppe}

1.1. "True" steppe. AK, Klyuchevskoy d., Krasny Yar s., lake "Krivaya puchina", loc. 1, Solonetzevataya steppe. I. Gorbunova. 


\section{Forest-steppe zone \\ Steppe}

2. Meadow steppe. NO, the Aleus river mouth, loc. 2, meadow steppe. I. Gorbunova.

Light coniferous forests

3.1. Pine and birch-pine forests. AK, Stripe pine forests "Lentochnye bory", Tsentralny d., Barnaul, highway "Lentochny Bor", loc. 3, 4, 5, birch-pine forest. Yuzhny s., b.g., loc. 6, birchpine forest. V. \& A. Vlasenko. AK, Pine forests "Priobskie ostrovnye bory", Troitsky d., Borovlyanka s., loc. 7, 8, birch-pine forest. Pervomaisky d., Losiha v., loc. 9, birch-pine forest; loc. 10, shrub pine-birch forest; loc. 11, shrub aspen-birch-pine forest; loc. 12, shrub birch-pine forest (planting). Talmensky d., Ozerki v., loc. 13, birch-pine forest. V. \& A. Vlasenko.

\section{Deciduous forests}

4.1. Birch forests. NO, Suzunsky d., Suzun s., loc. 14, riverine aspen-birch forest. Col. A. Zhukov, det. V. Vlasenko; Ibid, (LE 30512). Col. A. Zhukov., det. M. Bondartseva. AK, Talmensky d., Vypolzovo v., loc. 15, birch forest. V. \& A. Vlasenko. NO, Chanovsky d., "Starye Karachi" v., loc. 16, birch and aspen-birch forests. Col. N. Perova, det. V. Vlasenko; Ibid. N. Perova.

5.1. Willow communities and shrubs. NO, Maslyaninsky d., Kudrino s., the Inya riv., loc. 17, shrubs of the river bottomland. V. \& A. Vlasenko.

\section{Subtaiga zone}

Light coniferous forests

3.2. Pine and birch-pine forests. NO, Novosibirsk, natural forest within the boundaries of Akademgorodok, loc. 18, birch-pine forest. Akademgorodok, b.g., natural forests, loc. 19, birchpine forest; "Zaeltsovsky bor", loc. 20, birch-pine forest. V. \& A. Vlasenko.

\section{Deciduous forests}

4.2. Birch forests. NO, Novosibirsk, Akademgorodok, b.g., natural forests, loc. 21, birch forest.

6. Aspen forest. Ibid, loc. 22, aspen forest in the ravines.

5.2. Willow communities and shrubs. Ibid, loc. 23 , shrubs in a ravines; loc. 24 , shrubs in forest in depressions; the Zyrianka riv., loc. 25, riverine shrub (Salix, Padus) and shrubs of the river bottomland (Salix).

\section{Anthropogenic vegetation in cities}

7.1. Plantings in the botanical gardens. AK, Tsentralny d., Barnaul, Research Institute of Horticulture for Siberia, loc. 26, plantings. Col. A. Zhukov, det. V. Vlasenko. NO, Novosibirsk, Akademgorodok, b.g., loc. 27, plantings in the arboretum.

7.2. Plantings in cities. NO, Novosibirsk, Akademgorodok, loc. 28, Morskoy pr. 25, plantings; loc. 29, Ivanova st. 15, plantings.

Mountain area

Mountain steppe zone

Steppe

1.2. "True" steppe. AR, South-Eastern Altai, loc. 30, steppe (Mukhin et al., 2008).

Mountain forest-steppe zone

Light coniferous forests

8. "Parkovye" larch forests. AR, Kosh-Agach d., Kurai v., the Chichke riv., loc. 31, riverine gallery larch forest (with Salix). V. \& A. Vlasenko. 
Deciduous forests

9. Willow-birch riverin forests. AK, Kurinsky d., Kolivan v., the Loktevka riv., loc. 32, riverine shrub birch forest. V. Vlasenko. Charyshsky d., $5 \mathrm{~km}$ from the Tigirek v., headwaters Large Tigirek, loc. 33, riverine shrub birch forest. Col. Yu. Chubarova, det. V. Vlasenko. Krasnoshchokovsky d., $5 \mathrm{~km}$ from the Tigirek v., the mountain Schlyapnaya, loc. 34, riverine shrub birch forest. V. Vlasenko; Ibid. Col. Yu. Chubarova, det. V. Vlasenko. The Small Tigirek riv., at the Cordon, loc. 35, riverine shrub birch forest; the Small Tigirek riv., at the Inya riv., loc. 36, riverine shrub birch forest (with Populus). Zmeinogorsky d., $8 \mathrm{~km}$ from the Tigirek v., the Large Tigirek riv., loc. 37, riverine birch forest. V. \& A. Vlasenko.

\section{Mountain subtaiga zone \\ Deciduous forests}

10. Birch-aspen "Chernevye" forests. NO, Salair Ridge, Toguchinsky d., a former settlement Kotorovo, loc. 38, Col. N. Perova, det. V. Vlasenko; Ibid. Col. and det. N. Perova. "Osinniki", loc. 39, aspen forest. Col. A. Zhukov, det. M. Bondarzeva (LE 31425). Iskitimsky d., loc. 40, aspen forest. Col. N. Perova, det. V. Vlasenko. AR, Maiminsky d., Manzherok v., loc. 41, birch-aspen forest. O. Ermolaeva (LE 31174, 31165). Ust-Koksinsky d., the Kaytanak riv., loc. 42, birch-aspen forest (LE 31347). M. Bondarzeva.

4.3. Birch forests. NO, Iskitimsky d., Novososedovo v., "Kamenistaya steppe”, loc. 43, birch forest. V. \& A. Vlasenko.

Light coniferous forests

3.3. Pine and birch-pine forests. NO, Iskitimsky d., Novososedovo v., "Berdskie skaly", loc. 44, aspen-birch-pine forest. V. \& A. Vlasenko. Toguchinsky d., Mirny s., loc. 45, birch-pine forest. Col. N. Perova, det. V. Vlasenko. Ibid. Col. N. Lashchinsky, det. V. Vlasenko. Ibid. A. Zhukov.

Mountain taiga zone

Dark coniferous forests

11. Aspen-fir "Chernevaya taiga". AK, Kurinsky d., Kolivan v., 3 km. from Lake "Beloe", loc. 46, birch-aspen-fir forest; Krasnoshchekovsky d., Tigirek v., moun. "Chaynaya", loc. 47, shrub birch-fir forest; Charyshsky d., moun. "Lvinyi kamen", loc. 48, birch-aspen-fir forest; Zmeinogorsky d., $8 \mathrm{~km}$ from the Tigirek v., the Large Tigirek riv., loc. 49, shrub birch-aspen-fir forest. V. \& A. Vlasenko. AR, Chemalsky d., the Cuba riv., loc. 50, birch-fir forest. Col. A. Zhukov, det. V. Vlasenko. Choysky d., loc. 51, R. Singer, L. Vasilyeva (LE 30747). Turochaksky d., Lake Teletskoe, loc. 52 (Barsukova, 1998). Ibid, Artybash v., loc. 53, (LE 208327, 208318). Col. and det. R. Singer. Ibid, loc. 54 (LE 208312). Col. R. Singer, L. Vasilieva. NO, Salair Ridge, Toguchinsky d., a former settlement Kotorovo, loc. 55, aspen-fir forests. Col. N. Perova, det. V. Vlasenko; Ibid. N. Perova. Mirny s., loc. 56, birch-spruce-fir forest. N. Perova. Poldnevoy v., loc. 57, aspen-fir forest. Col. N. Perova, det. V. Vlasenko. KO, moun. Shoriya, Novokuznetsky d., Kuznetsovo v., loc. 58, aspen-fir-linden forest. Col. N. Perova, det. V. Vlasenko; Malinovka v., loc. 59, aspen-fir-linden forest; Tashtagolsky d., watershed Large the Tesch-Tamala riv., loc. 60, birchlinden and birch-fir-linden forests. N. Perova. Ibid. Col. N. Perova, det. V. Vlasenko. Mundybash s., loc. 61, linden forest. Col. N. Perova, det. V. Vlasenko.

12. Mountain valley spruce and larch-spruce forests. AR, Chemalsky d., the Cuba riv., loc. 62, willow-birch-fir forest. Col. A. Zhukov, det. V. Vlasenko; Ongudai d., the Chike-Taman mountain pass, the Large Ilgumen riv., loc. 63, valley willow-birch-spruce forest; Seminskii pass right, river Sarlyk, loc. 64, birch-spruce forest. V. \& A. Vlasenko. Ust-Koksinsky d., the Kaytanak riv., loc. 65, M. Bondarzeva (LE 30876).

Shrub vegetation

13. Shrub polydominant communities. AK, Zmeinogorsky d., Large Tigirek riv., Tigirek v., loc. 66, shrubs (Padus, Caragana, Crataegus). V. \& A. Vlasenko. 


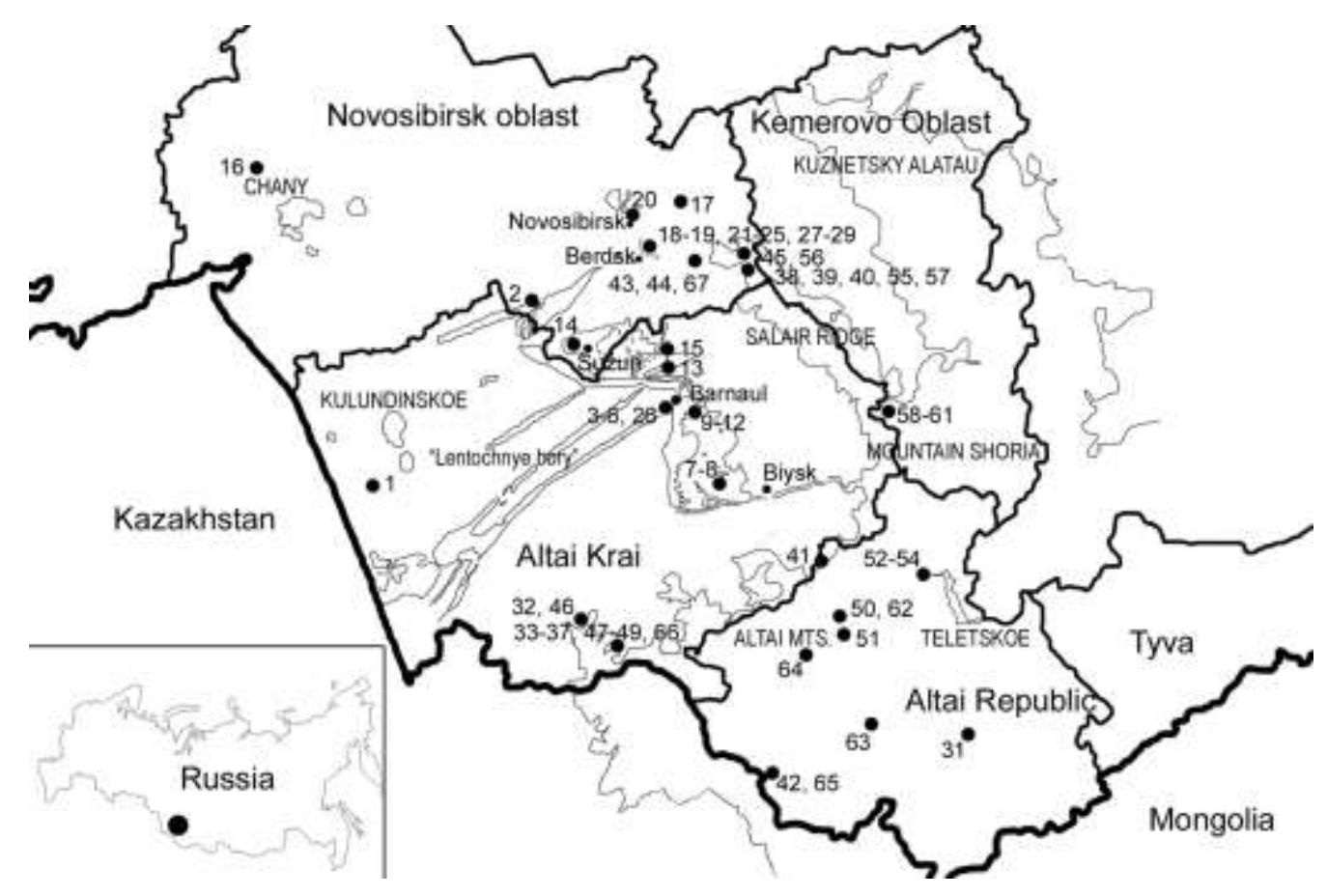

Fig. 1 - Map of the study area. Studied localities.

14. Shrubs on the scree "Kurumakh". NO, Iskitimsky d., Novososedovo v., "Berdskie skaly", the mountain "Zveroboy", the scree, loc. 67, shrubs (Caragana, Sambucus, Spirea). V. \& A. Vlasenko.

\section{Results}

\section{Key to Polyporus species}

1. Basidiocarps with branched stipes, arising from a common base, pores 1-3 per mm, spores 7.5-

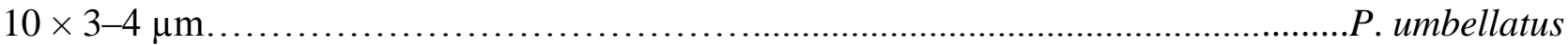
1. Basidiocarps with unbranched stipes, single or clustered or with rudimentary stipes ...2

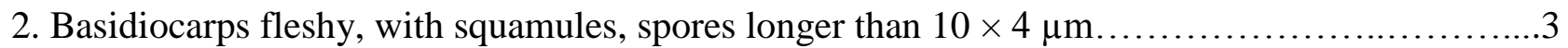

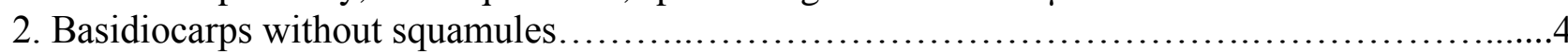

3. Basidiocarps large, context thick, stipe black at the base, formed by brown hyphae, pores 1-2 per

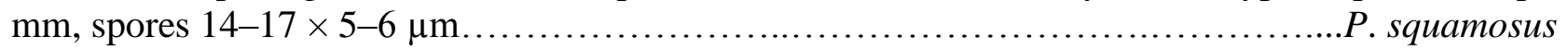
3. Basidiocarps thinner, context thin, stipe finely fimbriate, without brown hyphae, pores $1-2$ per

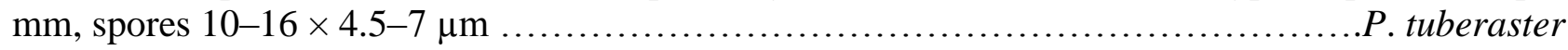

4. Basidiocarps coriaceous, stipe black at the base, formed by black cuticle......................5

4. Basidiocarps without a black cuticle on the stipe (may be present in old specimens) ..............8

5. Pileus white to light tobacco brown, pores $7-9$ per mm, spores $7-10 \times 3-4 \mu \mathrm{m} \ldots \ldots \ldots \ldots$. . varius

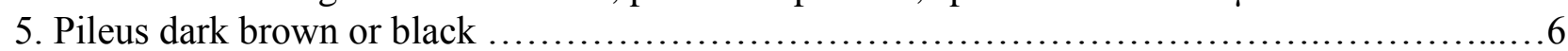

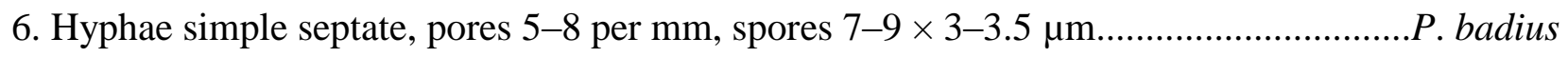

6. Hyphae whith clamps............................................................. 7 
8. Basidiocarps centrally stipitate .9

8. Basidiocarps laterally stipitate or substipitate.............................................

9. Basidiocarps growing on roots of steppe grasses (usually Stipa) P. rhizophilus

9. Basidiocarps growing on wood.

10. Pores $1-2$ per $\mathrm{mm}$, hexagonal, spores $7-9 \times 2.5-3.2 \mu \mathrm{m}$. P. arcularius 10. Pores $3-7$ per $\mathrm{mm}$

11. Pores 3-4 per $\mathrm{mm}$, spores $6-7 \times 2-2.5 \mu \mathrm{m}$. P. brumalis 11. Pores $5-7$ per $\mathrm{mm}$, spores $5-7 \times 2 \mu \mathrm{m}$. P. ciliatus

12. Basidiocarps attached to the substrate by a narrow base, pores $1-3$ per $\mathrm{mm}$, spores $6.5-10 \times$ 2.5-3.4 $\mu \mathrm{m}$, on Populus. .P.pseudobetulinus

12. Basidiocarps substipitate. .13

13. Basidiocarps laterally stipitate, flat, flabelliform, pores radially elongated, $1-2$ per $\mathrm{mm}$, spores $10-14 \times 3.5-5 \mu \mathrm{m}$ P. alveolaris

13. Basidiocarps substipitate, convex to flat, pores $1-5$ per $\mathrm{mm}$, spores $8.5-12.5 \times 3.5-5 \mu \mathrm{m}$, on Salix. P. choseniae

\section{Synopsis of Polyporus species}

Polyporus alveolaris (DC.) Bondartsev et Singer, 1941, Annls mycol. 39 (1): 58. Neofavolus alveolaris (DeCandolle) Sotome et T. Hatt., 2013, Fungal Diversity 58 (1): 250. Fig. $2 \mathrm{~A}$

Rare. Grows on dead wood, on deciduous trees: Caragana arborescens, Sorbus sibirica, Rhododendron daurica. Hab. 11. Loc. 49, 50, 51, 52, 58.
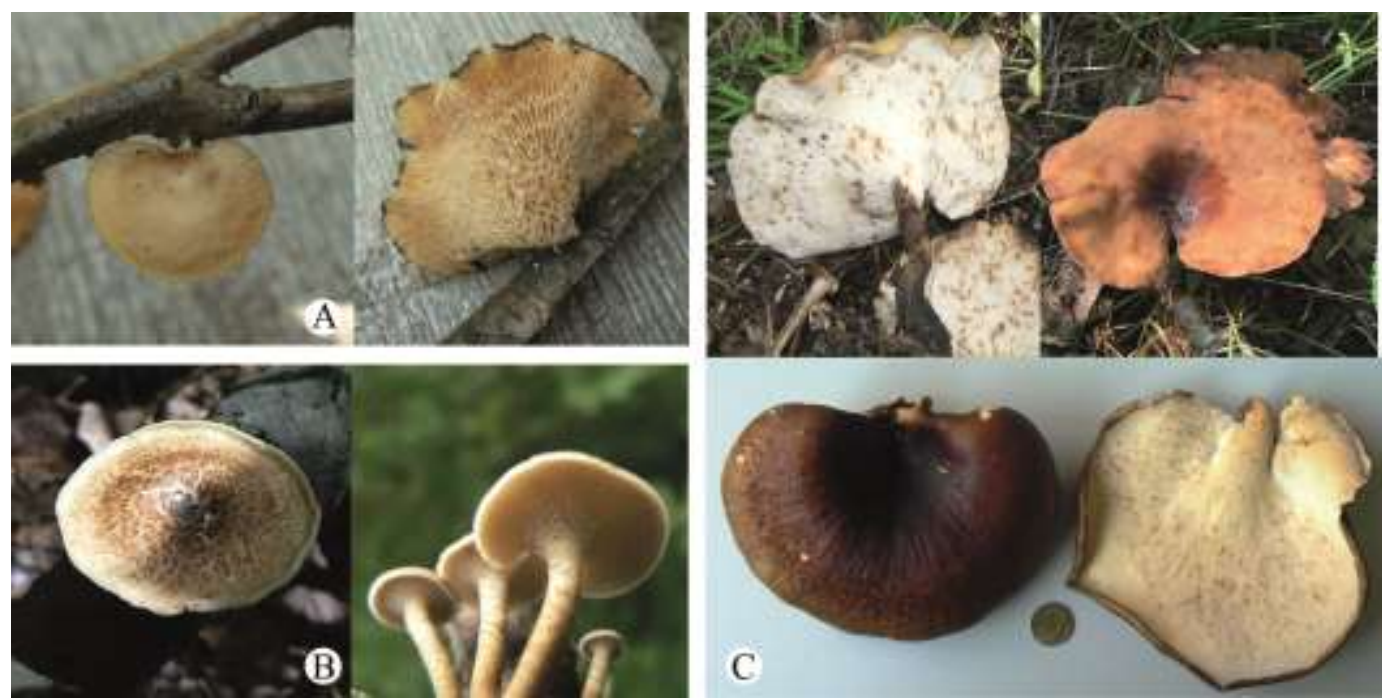

Fig. 2 - A: P. alveolaris. B: P. arcularius. C: P. badius.

Polyporus arcularius (Batsch) Fr., 1821, Syst. mycol. (Lundae) 1: 342. Fig. 2B

Abundant. Grows on dead wood, on deciduous trees: Betula pendula, Padus avium, Populus tremula, Salix spp., Sambucus racemosa. Hab. 3.1, 3.3, 5.1, 5.2, 9, 10, 11, 13, 14. Loc. 3, 4, 10, 11, $12,13,17,23,25,34,37,40,44,45,49,53,55,66,67$. 
Polyporus badius (Pers.) Schwein, 1832, Trans. Am. phil. Soc., New Series 4 (2): 155. Polyporus picipes Fr., 1838, Epicr. syst. mycol.: 440. - Polyporus durus (Timm) Kreisel, 1984, Boletus, SchrReihe 1: 30. - Royoporus badius (Pers.) A.B. De, 1997, Mycotaxon 65: 471. Fig. 2C

Abundant. Grows on dead wood, on deciduous trees: B. pendula, P. tremula, Salix spp., Tilia cordata. Hab. 3.2 , 3.3 , 4.1, 4.2, 6, 7.1, 9, 10, 11, 12. Loc. 14, 18, 19, 21, 22, 27, 33, 34, 35, 39, 41, $44,45,46,49,55,56,59,60,63$.

Polyporus brumalis (Pers.) Fr., 1818, Observ. mycol. 2: 255. Fig. 3A

Abundant. Grows on dead wood, on deciduous trees: B. pendula, Salix spp., P. avium, P. tremula, T. cordata. Hab. 3.1, 3.2, 3.3, 4.1, 4.2, 5.2, 6, 7.1, 11. Loc. 3, 6, 8, 9, 16, 18, 19, 20, 21, 22, $23,24,25,27,45,55,60$.

Polyporus choseniae (Vassilkov) Parmasto, 1975, Folia cryptog. Estonica 5: 35. Fig. 3B

Occasional. Grows on dead wood, on deciduous trees: Salix spp. Hab. 8. Loc. 31.

Polyporus ciliatus Fr., 1815, Observ. mycol. 1: 123. Fig. 3C

Abundant. Grows on dead wood, on deciduous and dark coniferous trees: B. pendula, P. tremula, P. avium, Salix spp., Pinus sibirica. Hab. 3.1, 3.3, 4.1, 5.2, 9, 10, 11, 12. Loc. 4, 9, 10, 12 , $15,16,23,25,32,38,44,45,46,55,65$.

Polyporus melanopus (Pers.) Fr., 1821, Syst. mycol. 1: 347. Fig. 3D

Abundant. Grows on dead wood, on deciduous and dark coniferous trees: B. pendula, Salix spp., Abies sibirica, P. tremula. Hab. 3.1, 3.2, 3.3, 4.1, 7.1, 9, 11. Loc. 7, 15, 16, 19, 27, 36, 37, 45, 46, 48, 49, 55, 57.
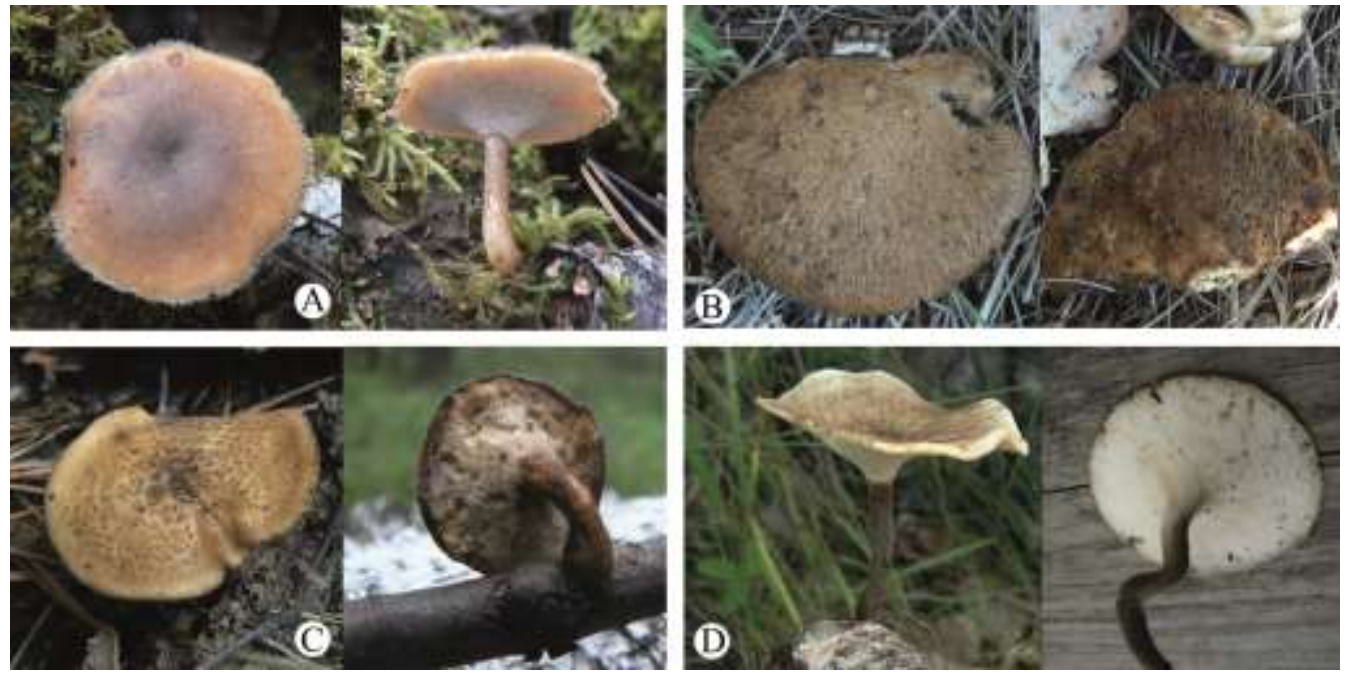

Fig 3 - A: P. brumalis. B: P. choseniae. C: P. ciliatus. D: P. melanopus.

Polyporus pseudobetulinus (Murashk. ex Pilat) Thorn, Kotir. et Niemela, 1990, Mycologia 82 (5): 583. Fig. 4A

Common. Grows on dead wood, on deciduous trees: P. tremula. Hab. 3.3, 4.1, 9, 11. Loc. 14, $36,45,49$.

Polyporus rhizophilus (Pat.) Sacc., 1894, J. Bot., Paris 8: 219. Fig. 4B

Occasional. Parasite of roots of grasses of the family Poaceae: Stipa spp. Hab. 1.1, 1.2, 2. Loc. 1, 2. 30.

Polyporus squamosus (Huds.) Fr., 1821, Syst. mycol. 1: 343. Fig. 4C 
Common. Grows on dead wood, on deciduous trees: Salix sp., Malus sp. Hab. 7.2, 12. Loc. $28,29,62,63$.

Polyporus tubaeformis (P. Karst.) Ryvarden et Gilb., 1993, Syn. Fung. 7: 578. Fig. 4D Rare. Grows on dead wood, on dark coniferous trees: A. sibirica. Hab. 11. Loc. 57.

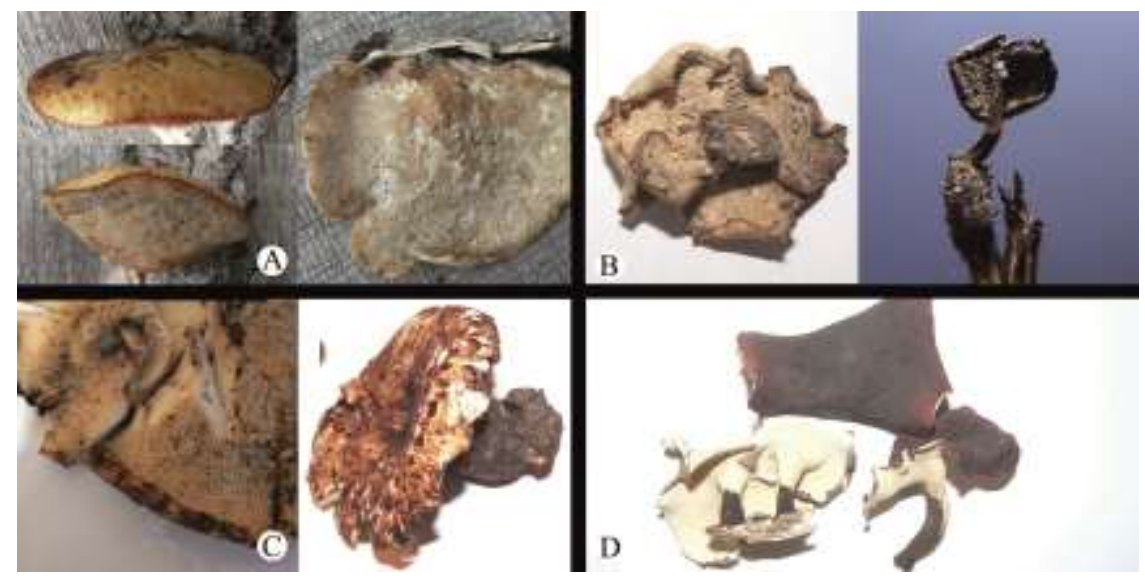

Fig 4 - A: P. pseudobetulinus. B: P. rhizophilus. C: P. squamosus. D: P. tubaeformis.

Polyporus tuberaster (Jacq. ex Pers.). Fr., 1821, Syst. mycol. 1: 347. - Polyporus coronatus Rostk., 1848, Deutschl. Fl., 3 Abt. (Pilze Deutschl.) 27-28: 33. - Polyporus forquignonii Quél., 1885, Compt. Rend. Assoc. Franç. Avancem. Sci. 13: 281. - Polyporus lentus Berk., 1860, Outl. Brit. Fung.: 237. Fig. 5A

Abundant. Grows on dead wood, on deciduous trees: P. tremula, Salix spp., T. cordata, Alnus fruticosa, Juglans mangurica. Hab. 3.1, 4.1, 7.1, 11. Loc. 5, 10, 16, 26, 54, 55, 60, 61.

Polyporus umbellatus (Pers.) Fr., 1821, Syst. mycol. 1: 354. - Dendropolyporus umbellatus (Pers.) Jülich, 1982, Biblthca Mycol. 85(6): 400. Fig. 5B

Rare. Grows on dead wood, on deciduous trees: Salix spp. Hab. 9. Loc. 34.

Polyporus varius (Pers.) Fr., 1821, Syst. mycol. 1: 352. Fig. 5C

Abundant. Grows on dead wood, on deciduous and light coniferous trees: B. pendula, B. microphylla, P. tremula, P. avium, Larix sibirica, Crataegus sanguinea, Salix spp. Hab. 3.1, 3.2, 3.3, 4.1, 4.2, 4.3, 5.2, 6, 7.1, 8, 9, 10, 11, 12. Loc. 5, 8, 10, 13, 15, 16, 18, 21, 22, 23, 24, 27, 31, 42, 32, $37,39,43,44,45,47,49,55,56,63,64$.
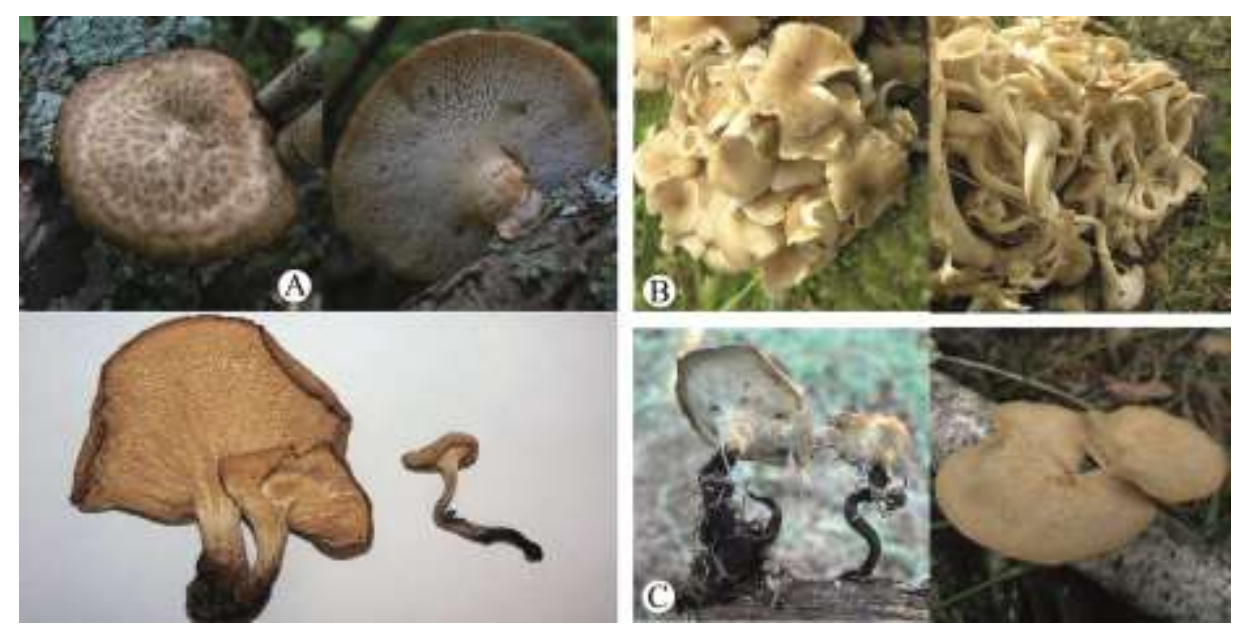

Fig. 5 - A: P. tuberaster. B: P. umbellatus. C: P. varius. 


\section{Discussion}

This study was based on a total of 260 records representing 14 species of the genus Polyporus south of Western Siberia. Rare species: P. umbellatus $(0,4 \%$ of all records), P. tubaeformis $(0,4$ $\%)$. Occasional species: $P$. chozeniae $(0,8 \%)$, P. rhizophilus $(1,2 \%)$. Common species: $P$. squamosus $(1,5 \%)$, P. alveolaris $(1,9 \%), P$. pseudobetulinus $(2,7 \%)$. Abundant species: $P$. tuberaster (4,6 \%), P. melanopus (5,8\%), P. arcularius $(10,0 \%), P$. ciliatus $(11,2 \%), P$. badius $(13,8 \%)$, P. brumalis $(16,9 \%), P$. varius $(28,8 \%)$.

The substrate differentiation of species from the genus Polyporus varies. Most species have a broad substrate spectrum, numbering 6 (P. varius), 5 ( $P$. arcularius, $P$. brumalis, $P$. ciliatus, $P$. tuberaster) or 4 (P. badius, $P$. melanopus) species of woody plants. Also it should be noted that all these species are frequently occurring. Common species are coincided with 2 (P. squamosus) and 3 $(P$. alveolaris) substrates. All other species have a narrow substrate spectrum and are coincided with one type of substrate - P. tremula ( $P$. pseudobetulinus), Salix spp. ( $P$. chozeniae и $P$. umbellatus), A. sibirica. (P. tubaeformis), and steppe grasses (P. rhizophilus).

Most species grow on wood of deciduous trees (12 species), of these 3 species (P. ciliatus, $P$. melanopus, $P$. varius) can grow on coniferous trees. On conifers in general can grow 4 species, of which only $P$. tubaeformis found only on conifers. 1 species ( $P$. rhizophilus) not associated to the wood.

Substrates of fungi were represented 11 species of angiosperms, 3 species of gymnosperms woody plants and steppe grasses. Species are distributed over the substrates as follows: on Salix spp. (10 species), P. tremula (8), Betula spp. (6), P. avium (4), T. cordata (3), A. sibirica (2). In other substrates are growing 1 species: S. sibirica, C. arborescens, A. fruticosa, C. sanguinea, J. mangurica, Malus spp., S. racemosa, Rh. dauricum, L. sibirica, P. sibirica, herbs.

All the findings on Sorbus, Caragana, Rhododendron in mountain area and belong to the $P$. alveolaris. Species $P$. arcularius grows on S. racemosa in the mountains scree bush communities. Only P. tuberaster was found on A. fruticosa and J. mangurica, P. squamosus - on Malus spp.

Species of the genus Polyporus on coniferous trees grow only in the mountainous regions. On L. sibirica grow only $P$. varius. On A. sibirica grow only P. tubaeformis and P. melanopus, on P. sibirica - only P. ciliatus.

Biotope differentiation of species of the genus Polyporus significantly varies. We differentiated the biotopes studied by identified plant formations which number in 14. One type of formations may be observed in different latitudinal zones and altitudinal zones, so they are divided in separate groups. Thus, taking into consideration zonal distribution, 21 major types of plant communities were identified.

Most of the species are spread in many communities: $P$. arcularius, $P$. badius, $P$. brumalis, $P$. ciliatus, $P$. melanopus, $P$. tuberaster, $P$. varius. All these species are different of frequent occurrence and have the widest range of substrates. Other species have narrow biotopical differentiation: P. pseudobetulinus (4), P. rhizophilus (3). Only one type of communities had 4 species: $P$. alveolaris and $P$. tubaeformis inhabit "chernevaya" taiga; $P$. chozeniae - riverine habitats in the "Parkovye" larch forests, P. umbellatus - willow-birch riverin forests.

The distribution of species significantly differs depending on the type of plant community. Most diversity of species observed in the aspen-fir forests "Chernevaya taiga" (10 species).

Seven types were identified among plant formations. Species are distributed thereon as follows (in descending order): dark coniferous forests (11 species), light coniferous forests (9), deciduous forests (9), anthropogenic vegetation in cities (6), scrub vegetation (1), "true" steppe (1), meadow steppe (1).

The analysis of distribution on the vegetation types shows that all 14 species of the genus Polyporus can be found in the natural plant communities, including 13 species in the forests, 1 species in the shrub vegetation (but 4 species in the shrub communities of forests), 1 species in the steppe. Six species are found in the anthropogenic vegetation.

In general, 10 species were found in the plain area, 14 species were found in the mountain systems, as well as for the entire area of study. The analysis of the zonal distribution of species 
shows that the most diversity of species of the genus Polyporus is observed in the mountain-taiga zone. $P$. alveolaris and $P$. chozeniae are specific for the mountains in the south of Western Siberia.

\section{Acknowledgements}

The work was supported by state project VI.52.1.3. "Biodiversity of algae, lichens, fungi of North Asia, the role in ecosystems, spatial and temporal organization, evaluation of the current state and monitoring"; Program of RAS 30.13 "Inventory diversity of algae, lichens and fungi of Altai-Sayan Ecoregion"; Grant of the Government of the Novosibirsk Oblast "Biodiversity conservation and study of fungi and protists of nature monuments of Novosibirsk Oblast "Berdskie skaly" and "Kamenistaya step u sela Novososedovo".

\section{References}

Barsukova TN. 1997. - Xylotrophic fungi and slime molds of Altai reserve on fees in 1995. Trudy Tzentralno-chernozemnogo gosudarstvennogo zapovednika 15, 203-208. (in Russian).

Barsukova TN. 1998. - Xylotrophic basidiomycetes of Altai state reserve. Mikologiya i fitopatologiya 32(5), 11-17. (in Russian).

Barsukova TN. 1999. - Addition to the flora of xylotrophic basidiomycetes of Altai state reserve. Mikologiya i fitopatologiya 33(5), 319-321. (in Russian).

Gilbertson RL, Ryvarden L. 1986. - North American polypores. Vol. 1: Abortiporus-Lindtneria. Fungiflora, Oslo, Norway.

Kovalenko AE. 1992. - On the flora agarikoid fungi of Altai reserve // Novosti sistematii nizshich rasteniy 28, 61-67. (in Russian).

Lindequist U, Niedermeyer THJ, Julich WD. 2005. - The Pharmacological potential of mushrooms. Alternative Medicine (2)3, 263-265.

Mukhin VA, Knudsen X, Ushakova NV, Korfiksen P. 2008. - Bracket fungi of Gorny Altai / Bioraznoobrazie, problemy ekologii Gornogo Altaya i sopredelnych regionov. RIO-GAGU, Gorno-Altaisk. (in Russian).

Núñez M, Ryvarden L. 1995. - Polyporus (Basidiomycotina) and related genera. Fungiflora, Oslo, Norway.

Ryvarden L, Melo I. 2014. - Poroid fungi of Europe. Fungiflora, Oslo, Norway.

Stephenson SL, Laursen GA. 1993. - Preliminary report on the distribution and ecology of myxomycetes in Alaskan tundra. Arctic Alpine Mycolgy 150, 251-257.

Teplyakova TV, Psurtseva NV, Kosogova TA, Mazurkova NA, Khanin VA, Vlasenko VA. 2012. Antiviral activity of polyporoid mushrooms (higher basidiomycetes) from Altai Mountains (Russia) // International Journal of Medicinal Mushrooms 14(1), 37-45.

Vlasenko VA. 2010. - Novelties of the genus Polyporus (Polyporaceae, Basidiomycota) for mycobiota of Altai // Rastitelnyy mir Aziatskoy Rossii (5)1, 29-32. (in Russian).

Vlasenko VA. 2011. - Genus Polyporus (Polyporaceae, Basidiomycota) in the forest-steppe zone of Western Siberia // Rastitelnyy mir Aziatskoy Rossii. 8(2): 9-14. (in Russian).

Zhukov AM. 1980. - Wood-decay fungi of Priobye / Vodorosli, gribi i lishayniki yuga Sibiri. Nauka, Moscow. (in Russian).

Zhukov EA. 1995. - Aphyllophorales (Basidiomycetes) from Central Siberia. Mycotaxon 53, 437445. 